\title{
Seasonal changes in epidermal ceramides are linked to impaired barrier function in acne patients
}

DOI:

10.1111/exd.13499

\section{Document Version}

Accepted author manuscript

Link to publication record in Manchester Research Explorer

\section{Citation for published version (APA):}

Pappas, A., Kendall, A., Brownbridge, L., Batchvarova, N., \& Nicolaou, A. (2018). Seasonal changes in epidermal ceramides are linked to impaired barrier function in acne patients. Experimental Dermatology. https://doi.org/10.1111/exd.13499

\section{Published in:}

Experimental Dermatology

\section{Citing this paper}

Please note that where the full-text provided on Manchester Research Explorer is the Author Accepted Manuscript or Proof version this may differ from the final Published version. If citing, it is advised that you check and use the publisher's definitive version.

\section{General rights}

Copyright and moral rights for the publications made accessible in the Research Explorer are retained by the authors and/or other copyright owners and it is a condition of accessing publications that users recognise and abide by the legal requirements associated with these rights.

\section{Takedown policy}

If you believe that this document breaches copyright please refer to the University of Manchester's Takedown Procedures [http://man.ac.uk/04Y6Bo] or contact uml.scholarlycommunications@manchester.ac.uk providing relevant details, so we can investigate your claim.

\section{OPEN ACCESS}


DR. APOSTOLOS PAPPAS (Orcid ID : 0000-0001-7833-5204)

DR. ALEXANDRA C KENDALL (Orcid ID : 0000-0003-4419-0013)

PROF. ANNA NICOLAOU (Orcid ID : 0000-0002-1314-413X)

Article type : Methods Letter to the Editors

\section{Seasonal changes in epidermal ceramides are linked to impaired barrier function in acne patients}

Apostolos Pappas ${ }^{1}$, Alexandra C. Kendall ${ }^{2}$, Luke C. Brownbridge ${ }^{2}$, Nikoleta Batchvarova ${ }^{1}$, Anna Nicolaou ${ }^{2 *}$

${ }^{1}$ J\&J JOHNSON \& JOHNSON Consumer Inc., 199 Grandview Road, Skillman, NJ 08558, USA; ${ }^{2}$ Laboratory for Lipidomics and Lipid Biology, Division of Pharmacy and Optometry, School of Health Sciences, Faculty of Biology, Medicine and Health, The University of Manchester, Manchester Academic Health Science Centre, Manchester M13 9PL, UK.

*Corresponding Author: Professor Anna Nicolaou, Division of Pharmacy and Optometry,

School of Health Sciences, Faculty of Biology, Medicine and Health, University of Manchester, Manchester M13 9PL, UK. Email: anna.nicolaou@manchester.ac.uk

SHORT TITLE: Seasonal ceramide variation in acne patients

This article has been accepted for publication and undergone full peer review but has not been through the copyediting, typesetting, pagination and proofreading process, which may lead to differences between this version and the Version of Record. Please cite this article as doi: 10.1111/exd.13499

This article is protected by copyright. All rights reserved. 
The work was carried out in Skillman, NJ, USA and Manchester, UK.

\begin{abstract}
Abbreviations: SC, stratum corneum; CER, ceramide; TEWL, trans-epidermal water loss;
UPLC/ESI-MS/MS, ultraperformance-liquid-chromatography tandem mass-spectrometry
\end{abstract}

Key words: TEWL; epidermal lipids; stratum corneum; acylceramides; mass spectrometry

\begin{abstract}
Acne skin demonstrates increased transepidermal water loss (TEWL) compared with healthy skin, which may be due, in part, to altered ceramide levels. We analysed ceramides in the stratum corneum of healthy and acne skin, and studied seasonal variation over the course of a year. Using ultraperformance liquid chromatography with electrospray ionisation and tandem mass spectrometry (UPLC/ESI-MS/MS), we identified 283 ceramides. Acne-affected skin demonstrated overall lower levels of ceramides, with notable reductions in CER[NH] and CER[AH] ceramides, as well as the acylceramides CER[EOS] and CER $[E O H]$; these differences were more apparent in the winter months. Lower ceramide levels reflected an increase in TEWL in acne, compared with healthy skin, which partly resolves in the summer. Individual ceramide species with 18-carbon 6hydroxysphingosine $(\mathrm{H})$ bases (including CER[N(24)H(18)], CER[N(26)H(18)], CER[A(24)H(18)], CER[A(26)H(18)]) were significantly reduced in acne skin, suggesting that $\mathrm{CER}[\mathrm{NH}]$ and $\mathrm{CER}[\mathrm{AH}]$ species may be particularly important in a healthy skin barrier.
\end{abstract}

\title{
1. Background
}

Acne is a common multifactorial disease prevalent in adolescents [1], recently shown to involve reduced epidermal barrier function [2], with symptoms reportedly worsening in winter [3]. Although impaired barrier function correlates with reduced total sphingolipids in acne [4], there is a lack of detailed understanding of stratum corneum (SC) ceramide changes and their contribution to barrier function in the disease. Furthermore, seasonal variation in SC 
ceramides in healthy individuals has been reported, with acylceramides CER[EOS] found reduced in winter [5], but the picture in acne is less clear.

\section{Questions Addressed}

Aiming to compare acne with healthy skin, interrogate potential seasonal differences, and seek association with barrier function, we performed a detailed investigation of SC ceramides throughout the year.

\section{Experimental Design}

We studied adolescent males (aged 13-18yr) with $(n=7)$ and without $(n=10)$ acne over 12 months (females were excluded to avoid potential hormonal cycling effects in a small subject population). The study was conducted according to the Helsinki Declaration, with written informed consent, and approved by the Allendale Institutional Review Board. Cheek SC lipids were sampled in each season (February, April, August, November) using Leukoflex ${ }^{\circledR}$ tapes. A single tape-strip per donor was used (uppermost layer of SC) to extract ceramides. A total of 283 ceramides from 10 classes were identified and analyzed by ultra-performanceliquid-chromatography coupled to electrospray-ionization tandem mass-spectrometry (UPLC/ESI-MS/MS) [6, 7] (Supplementary-S1). Relative semi-quantitation was performed using CER[N(25)S(18)] as internal standard, a ceramide found in negligible levels endogenously. This approach allows valid comparison between healthy and acne skin, and across seasons, in this case-control study. Ceramide quantities are reported as pmol/mg protein and are similar to those published previously from the analysis of SC ceramides in healthy subjects $[8,9]$ (Supplementary-S1); proportions of ceramide classes (mean \% of total ceramides) are also in agreement with previous analysis of cheek SC (SupplementaryS2) $[8,9]$. CER $[\mathrm{AH}]$ and CER[NH] were found to be the most abundant classes in cheek SC, 
while other body sites (e.g. forearm) show different compositions and contain less 6-hydroxyceramides and more phyto-ceramides [8-12].

\section{Results}

Acne-affected skin showed higher levels of TEWL (assessed by open-chambered evaporimeter) [13] than healthy skin year-round, with significant differences December to June, and September to November, indicating possible compromised barrier function (Supplementary-S3). No seasonal changes in acne symptoms (modified Cook's score) were observed. All ceramide classes demonstrated significant negative correlation with TEWL during at least one season, but only some negative correlations with acne symptoms [14]; TEWL did not correlate with symptoms (Supplementary-S4); so we compared ceramide class totals in healthy and acne skin (Fig.1).

Acne-affected skin showed lower levels of ceramides (Fig.1), with profound reductions compared to healthy in CER[NH] (February: 57\% p=0.004; April: $38 \% \mathrm{p}=0.001$ ), CER[AH] (February: 36\% p=0.003; April: 47\% p=0.006), CER[EOS] (February: 68\% p<0.0001; August: 71\% p=0.003; November: 40\% p=0.002) and CER[EOH] (February: 59\% $\mathrm{p}=0.006$ ). These differences equilibrated in August (Fig.1c) when TEWL differences diminished (Supplementary-S3), suggesting that changes in barrier function may be attributed not only to differential ceramide production in acne, but also to reduced levels of $\mathrm{CER}[\mathrm{NH}]$ and CER[AH] species.

Profiling of CER[NH] and CER[AH] species revealed lower levels in acne compared with healthy skin of $\operatorname{CER}[\mathrm{N}(24) \mathrm{H}(18)]$ (February, April, November: 46\%, 67\%, 37\% respectively; $\mathrm{p}<0.0001), \mathrm{CER}[\mathrm{N}(26) \mathrm{H}(18)]$ (February, April, August, November: 42\%, 63\%, 49\%, 42\% respectively; p<0.0001), CER[A(24)H(18)] (February, April, November: 40\%, 56\%, 29\% respectively; $\mathrm{p}<0.0001)$ ) and CER[A(26)H(18)] (February: 23\% p=0.04; April: 
$42 \% \mathrm{p}<0.0001$, November: $24 \% \mathrm{p}=0.0005$ ) (Fig.2). Reductions were also noted in CER[EOS] and CER[EOH] species with 18-carbon sphingoid bases (Fig.2): CER[E(18:2)O(30)S(18)] (February: 67\% p<0.0001, August: 75\% p=0.001; November: 37\% p=0.01); CER[E(18:2)O(30)H(18)] (February: 61\%, April: 69\%, August: 74\%, November: $54 \%$, all $\mathrm{p}<0.0001)$

\section{Conclusions}

This study shows that seasonal variations in skin ceramides are more pronounced in acne, with reductions in ceramide levels during winter months reflecting reduced barrier function, assessed as increased TEWL. Healthy skin produced higher levels of CER[NH] and $\mathrm{CER}[\mathrm{AH}]$ in winter, suggesting adaptation to temperature, humidity or UV changes, while acne-affected skin appears less able to do so. Currently, the mechanisms underlying seasonal changes in skin ceramides are not understood, but are likely to involve both the ceramide salvage and de novo biosynthesis pathways [7].

While CER[EOS] and CER[EOH] levels are crucial for SC organisation and barrier function $[15,16]$, the properties of 6-hydroxy-ceramides CER[AH] and CER[NH] are less well understood. Recent findings from studies using model membranes provide mixed evidence on their roles in barrier function. Model membranes with CER[NH] instead of CER[NS] had reduced ion permeability, although this was accompanied by increased water permeability [17]. Additionally, the presence of multiple hydroxy groups (three in CER[NH], four in CER[AH]) alters lipid packing in a way similar to inclusion of phyto-ceramides in model membranes $[18,19]$. The physiological relevance of these findings remains uncertain, and it seems likely that an effective barrier depends on the inclusion of correct proportions of different ceramide classes. As this is the first report on the prevalence of 6-hydroxyceramides in acne and their potential involvement in acne-related barrier dysfunction, further 
studies are needed to appreciate their exact role in SC structure and function, and the effect of seasonal changes on their production.

Interestingly, ceramide species found reduced in acne are all derivatives of the H18 sphingoid base, containing non-hydroxy (N) and $\alpha$-hydroxy (A) acyl chains with 24- and 26carbons CER[(N(24)H(18)]， CER[N(26)H(18)]， CER[A(24)H(18)]， CER[A(26)H(18)] (Fig.2). This profile may be attributed to high abundance of 18-carbon chains, although the biosynthetic reactions regulating these hydroxylated ceramides are not yet clear [20]. The $\mathrm{H}$ base appears to be skin-specific and present at substantial levels, and warrants further investigation in acne and other inflammatory conditions. The apparent failure of acneaffected skin to produce sufficient amounts of 6-hydroxy-ceramides suggests potential defects in the expression/activity of relevant enzymes; acne skin presents a useful system for their identification. This study demonstrates for the first time that changes in ceramide composition are associated with acne, and may lead to a better understanding of the compromised epidermal barrier in the disease, including the role of other epidermal lipids important for barrier function.

\section{ACKNOWLEDGEMENTS}

The study was supported by JOHNSON\&JOHNSON through a research grant to the University of Manchester. We thank Neil O'Hara for excellent technical support.

\section{AUTHORS CONTRIBUTION:}

AP, NB and AN were responsible for the study design. LCB performed mass spectrometry for lipid analysis. ACK analysed lipid data. ACK and AN drafted the manuscript. All authors performed critical revision of the manuscript. 


\section{CONFLICTS OF INTEREST}

This study was fully supported by JOHNSON\&JOHNSON Consumer Inc. (Skillman, NJ) and AP and NB are or were employees or contractors of JOHNSON \& JOHNSON at the time these studies were performed. AP and NB were involved in study design and the writing of the report.

\section{REFERENCES}

1. Tan J K, Bhate K. Br J Dermatol 2015: 172 Suppl 1: 3-12.

2. Meyer K, Pappas A, Dunn K, Cula G O, Seo I, Ruvolo E, Batchvarova N. J Drugs Dermatol 2015: 14: 593-601.

3. Gfesser M, Worret W-I. Int J Dermatol 1996: 35: 116-117.

4. $\quad$ Yamamoto A, Takenouchi K, Ito M. Arch Dermatol Res 1995: 287: 214-218.

5. Conti A, Rogers J, Verdejo P, Harding C R, Rawlings A V. Int J Cosmet Sci 1996: 18: 1-12.

6. Kendall A C, Pilkington S M, Massey K A, Sassano G, Rhodes L E, Nicolaou A. J Invest Dermatol 2015: 135: 1510-1520.

7. Kendall A C, Kiezel-Tsugunova M, Brownbridge L C, Harwood J L, Nicolaou A. Biochim Biophys Acta 2017: 1859: 1679-1689.

8. Masukawa $Y$, Narita H, Sato H, Naoe A, Kondo N, Sugai Y, Oba T, Homma R, Ishikawa J, Takagi Y, Kitahara T. J Lipid Res 2009: 50: 1708-1719.

9. Ishikawa J, Shimotoyodome $\mathrm{Y}$, Ito $\mathrm{S}$, Miyauchi Y, Fujimura T, Kitahara T, Hase T. Arch Dermatol Res 2012: 305: 151-162.

10. Janssens M, van Smeden J, Gooris G S, Bras W, Portale G, Caspers P J, Vreeken R J, Kezic S, Lavrijsen A P, Bouwstra J A. J Invest Dermatol 2011: 131: 2136-2138.

11. t'Kindt R, Jorge L, Dumont E, Couturon P, David F, Sandra P, Sandra K. Anal Chem 2012: 84: 403-411.

12. Ishikawa J, Narita H, Kondo N, Hotta M, Takagi Y, Masukawa Y, Kitahara T, Takema Y, Koyano S, Yamazaki S, Hatamochi A. J Invest Dermatol 2010: 130: 2511-2514.

13. Grove G L, Grove M J, Zerweck C, Pierce E. Skin Res Technol 1999: 5: 9-13.

14. Cook C H, Centner R L, Michaels S E. Arch Dermatol 1979: 115: 571-575.

15. Schreiner V, Gooris G S, Pfeiffer S, Lanzendorfer G, Wenck H, Diembeck W, Proksch E, Bouwstra J. J Invest Dermatol 2000: 114: 654-660.

16. Janssens M, van Smeden J, Gooris G S, Bras W, Portale G, Caspers P J, Vreeken R J, Hankemeier T, Kezic S, Wolterbeek R, Lavrijsen A P, Bouwstra J A. J Lipid Res 2012: 53: 2755-2766.

17. Kovacik A, Silarova M, Pullmannova P, Maixner J, Vavrova K. Langmuir 2017: 33: 2890-2899.

18. Kessner D, Brezesinski G, Funari S S, Dobner B, Neubert R H H. Chem Phys Lipids 2010: 163:

42-50.

19. Stahlberg S, Lange S, Dobner B, Huster D. Langmuir 2016: 32: 2023-2031.

20. Rabionet M, Gorgas K, Sandhoff R. Biochim Biophys Acta 2014: 1841: 422-434.

This article is protected by copyright. All rights reserved. 


\section{FIGURE LEGENDS}

Figure 1. The SC of acne skin shows reduced levels of CER[NH], CER[AH], CER[EOS] and CER[EOH] ceramides. SC lipids were sampled from the cheek skin of adolescent boys with ( $\mathrm{n}=7)$ and without $(\mathrm{n}=10)$ acne in February (a), April (b), August (c) and November (d). Individual ceramide species were analysed by UPLC/ESI-MS/MS and are presented as total ceramides per class, expressed as pmol/mg protein. In acne, total levels of CER[NH], CER[AH], CER[EOS] and CER[EOH] ceramides were reduced, with differences significant in the winter and spring, and mainly resolving in the summer and autumn. Data are expressed as individual points; lines represent mean \pm SD. Statistical analyses were performed using unpaired $t$-tests corrected for multiple comparisons.

Figure 2. In acne, individual ceramide species containing C18 sphingoid bases within the CER[NH], CER[AH], CER[EOS] and CER[EOH] classes demonstrated significant reductions compared with clear skin. Individual ceramide species were analysed using UPLC/ESI-MS/MS and multiple reaction monitoring, and are expressed as pmol/mg protein. In acne, ceramides CER[N(24)H(18)], CER[N(26)H(18)], CER[A(24)H(18)], CER[A(26)H(18)], CER[E(18:2)O(30)S(18)] and CER[E(18:2)O(30)H(18)] showed reduced expression year-round, although with some improvements in the summer. Data $(n=10$ healthy, $\mathrm{n}=7$ acne) are expressed as mean $\pm \mathrm{SD} . * * * * \mathrm{p}<0.0001, * * \mathrm{P}<0.01, * \mathrm{P}<0.05$. Statistical analyses were performed using unpaired $t$-tests corrected for multiple comparisons.

This article is protected by copyright. All rights reserved. 
a
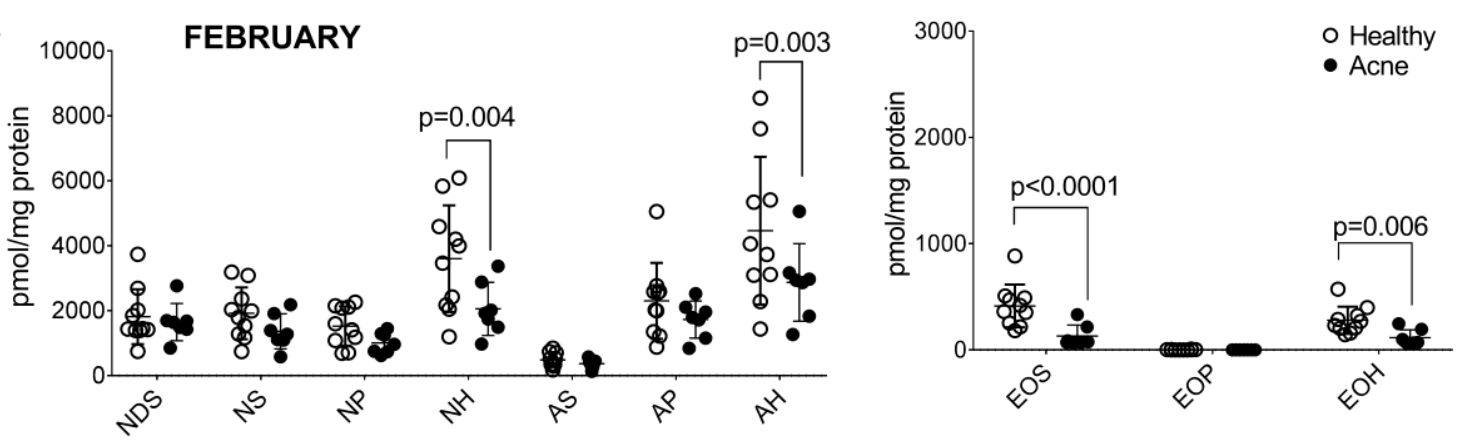

b
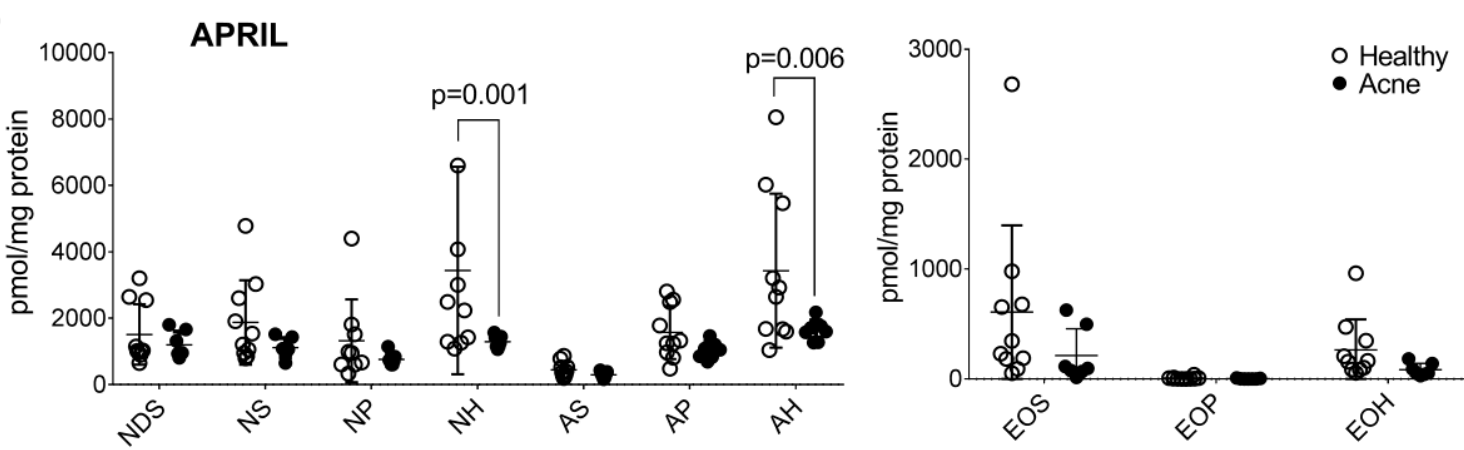

C
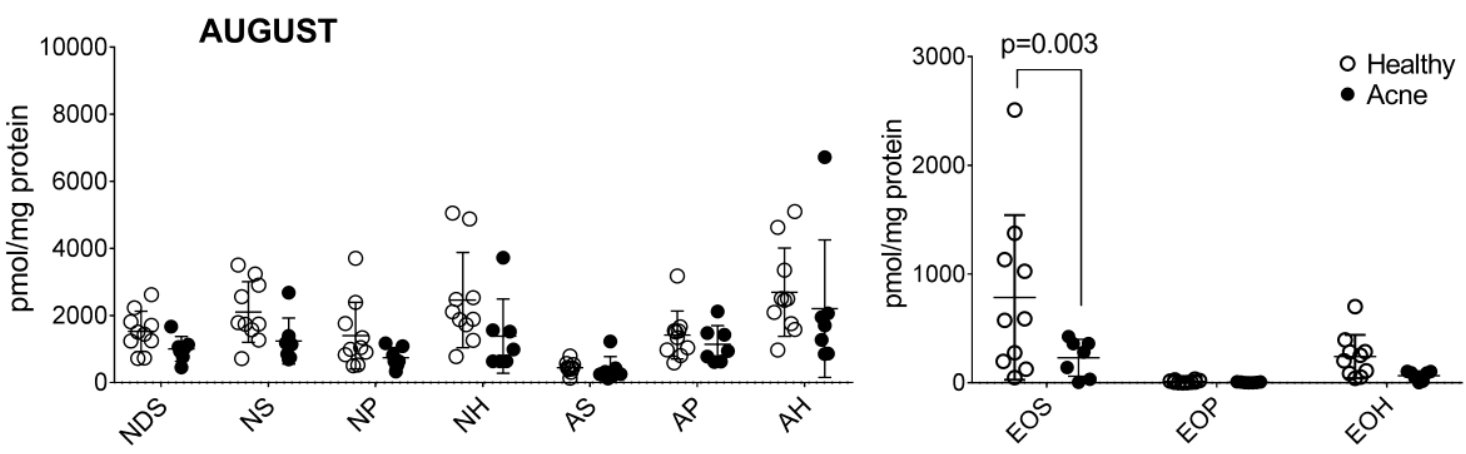

d
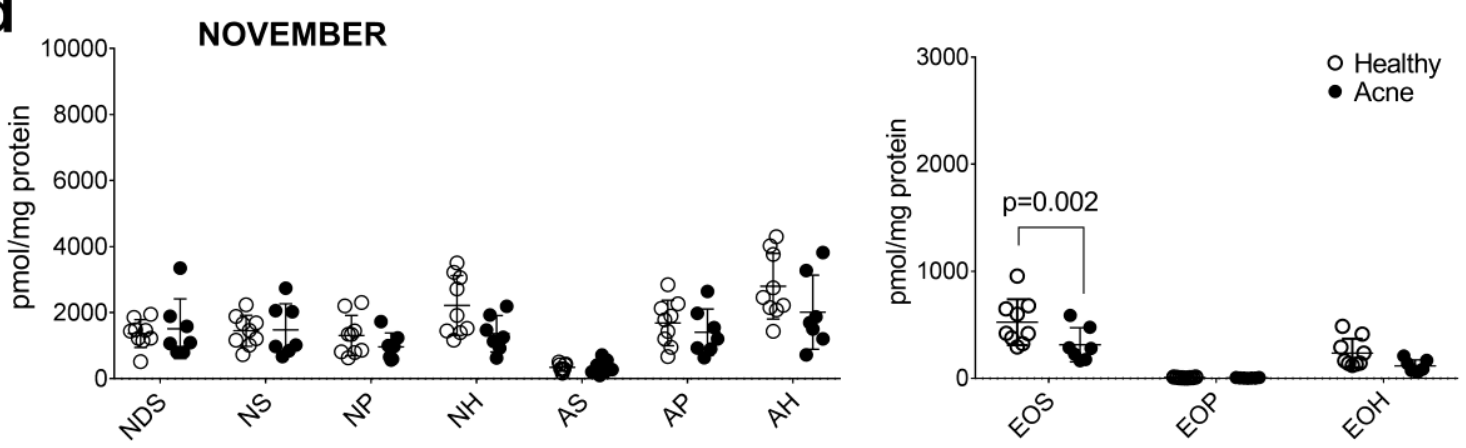

This article is protected by copyright. All rights reserved. 

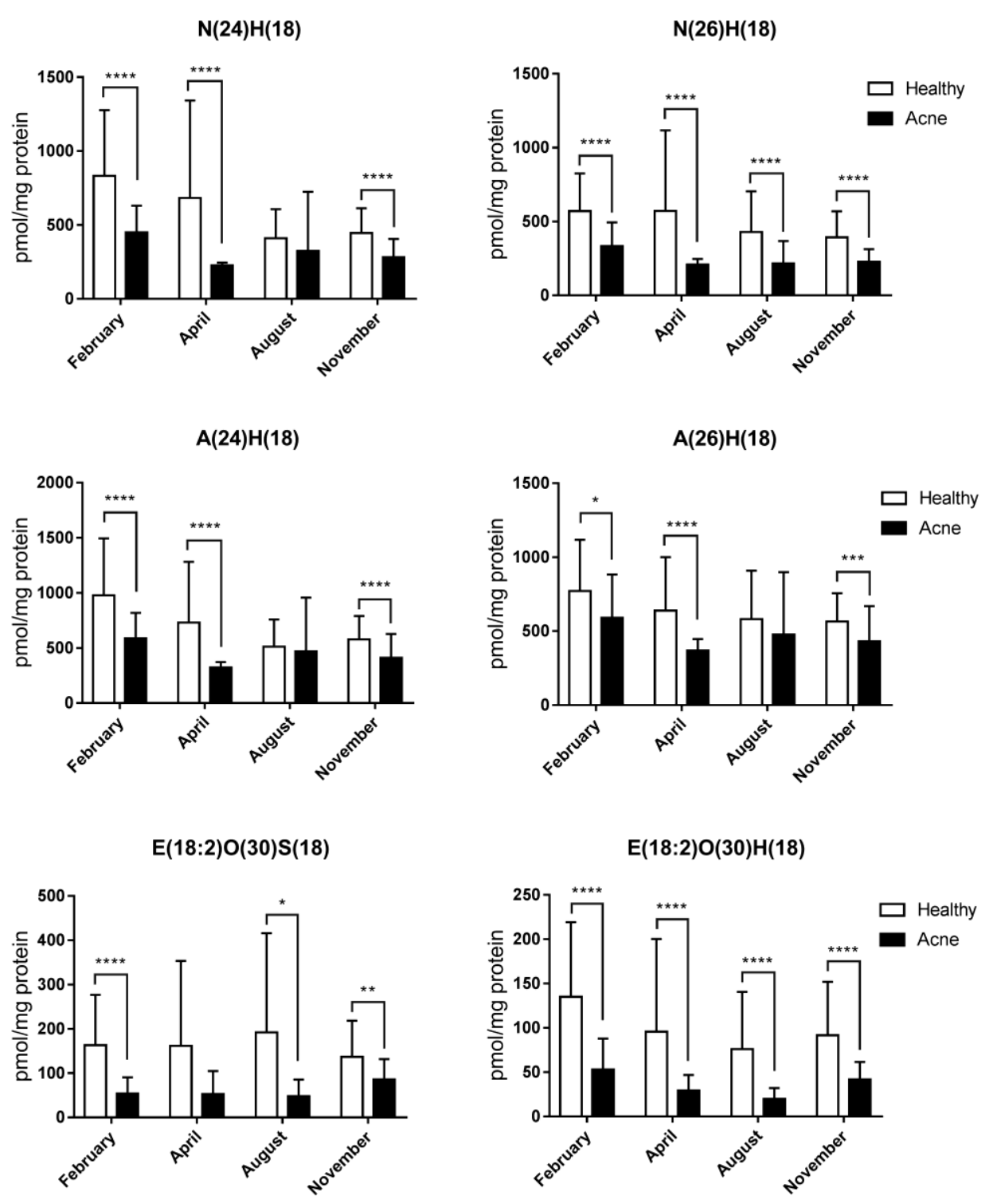

This article is protected by copyright. All rights reserved. 